\title{
Overview Potensi Panas Bumi di Provinsi Jawa Barat
}

\author{
Iwan Gunawan' ${ }^{1}$, Jaka Windarta ${ }^{1}$, Udi Harmoko ${ }^{2}$ \\ ${ }^{1}$ Magister Energi, Sekolah Pascasarjana, Universitas Diponegoro; \\ ${ }^{2}$ Departemen Fisika, Fakultas Sains dan Matematika, Universitas Diponegoro;
}

\begin{abstract}
Email :iwangunawan@students.undip.ac.id (I.G), jakawindarta@lecturer.undip.ac.id (J.W.), udiharmoko@fisika.fsm.undip.ac.id (U.H);
\end{abstract}

\begin{abstract}
Abstrak : Energi panas bumi termasuk dalam jenis energi terbarukan sehingga ketersediaannya tidak terpengaruh oleh kurangnya sumber energi dan kenaikan harga minyak fosil. Panas bumi termasuk energi ramah lingkungan yang menjadi salah satu keuntungan energi panas bumi. Secara umum tidak semua negara memiliki potensi energi panas bumi, hanya negara-negara yang dilintasi cincin api yang memiliki sumber energi panas bumi. Indonesia sebagai salah satu negara yang menyimpan potensi panas bumi ditunjukkan dengan adanya 117 gunung berapi aktif yang tersebar di seluruh pelosok tanah air. Energi panas bumi Indonesia memiliki potensi dan diperkirakan sekitar $40 \%$ dari potensi energi panas bumi dunia atau sekitar 29.544 MW. Namun, hanya sekitar 7,2\% atau sekitar 2130,7 MW ditahun 2019 yang dimanfaatkan sebagai energi listrik di dalam negeri. Pemerintah Indonesia terus berupaya meningkatkan kapasitas pembangkit listrik tenaga panas bumi. Pemerintah berencana untuk meningkatkan bauran pembangkit listrik tenaga panas bumi di Indonesia sebesar 7,2 GW pada tahun 2025 dan 17,6 GW pada tahun 2050. Jawa Barat sebagai salah satu provinsi di Indonesia memiliki potensi panas bumi yang besar dan 56\% pembangkit listrik panas bumi yang terpasang pada saat ini berasal dari provinsi Jawa Barat. Berdasarkan road map pengembangan panas bumi sampai tahun 2025, dengan target $39,5 \%$ potensi panas bumi yang akan dikembangkan berada di provinsi Jawa Barat.
\end{abstract}

Kata Kunci : Panas Bumi, Potensi, Road Map

\section{Pendahuluan}

Sebagai salah satu negara yang dilintasi ring of fire, Indonesia menyimpan potensi panas bumi dan hal ini ditunjukkan dengan adanya 117 gunung api aktif dan tersebar di seluruh pelosok tanah air dan tersebar di pulau Sumatera, Jawa, Nusa Tenggara, Maluku dan Sulawesi (Nasruddin et al, 2016). Potensi panas bumi di Indonesia tersebut diperkirakan sekitar 29.544 MW. Namun, hanya sekitar $7,2 \%$ yang dimanfaatkan sebagai energi listrik di dalam negeri. Indonesia memiliki potensi energi panas bumi terbesar di dunia, yang mencakup sekitar $40 \%$ dari potensi dunia. Pemerintah Indonesia terus berupaya meningkatkan bauran pembangkit listrik tenaga panas bumi dengan target 7,2 GW pada tahun 2025, dan 17,6 GW pada tahun 2050 (RUEN, 2017).

Dalam kamus KBBI arti kata geotermal adalah yang bersangkutan dengan panas yang berasal dari pusat bumi. Geothermal berasal dari kata Yunani; geo berarti bumi, dan termal berarti panas, dan dapat diartikan sebagai panas bumi atau energi yang dihasilkan dari bumi. Energi yang terkandung 
di dalam fluida panas bumi adalah air yang dapat berbentuk uap, cair dan atau keduanya sebagai campuran (Nasruddin et al, 2016). Energi panas bumi yang digunakan sebagai pembangkit listrik biasanya disebut sebagai pembangkit listrik tenaga panas bumi (PLTP) dan pembangkit listrik ini ramah lingkungan, dan sebagai pembangkit terbarukan dan berkelanjutan karena karakteristik sumber energinya (Alison \& Blodgett, 2012).

Secara umum pemanfaatan energi panas bumi di Indonesia dibagi menjadi dua jenis: penggunaan langsung dan tidak langsung. Pemanfaatan langsung memanfaatkan panas yang terkandung dalam fluida panas bumi untuk berbagai keperluan contohnya sebagai pemanas ruangan, pertanian/agroindustri, perikanan, pariwisata dan lainnya. Sedangkan pemanfaatan tidak langsung contohnya pemanfaatan untuk pembangkit listrik.

Klasifikasi utilisasi sumber geothermal berdasarkan themodinamika dan entalphi dari reservoir sebagaimana gambar 1. Berdasarkan Lindal diagram dikelompokan dalam temperatur fluida, entalpi panas bumi diklasifikasikan menjadi rendah, sedang dan tinggi (Ahmadi et al, 2020). Tabel 1 dapat dijadikan acuan untuk 5 kategori panas bumi yaitu: hot-water systems, twophase, liquid-dominated systems, low-enthalpy systems, twophase, liquid-dominated, medium-enthalpy system, two-phase, liquid-dominated-high-enthalpy system dan two-phase, vapor dominated systems (Eylem Kaya, 2011). Sistem energi panas bumi di negara ini umumnya sistem hidrotermal yang bersuhu tinggi yang lebih dari $225^{\circ} \mathrm{C}$, dan hanya sedikit sistem hidrotermal yang memilikinya suhu sekitar $150-225^{\circ} \mathrm{C}$. Meski potensi panas bumi besar di Indonesia, hingga Saat ini pemanfaatannya masih belum optimal, terutama untuk pemanfaatan sebagai pembangkit listrik (Nasruddin et al, 2016).

Tabel 1.

Klasifikasi sumber panas bumi berdasarkan enthalpy (Nasruddin et al, 2016)

\begin{tabular}{cccc}
\hline Category & & Temperature $(\mathrm{T})$ & Production Enthalphy $(\mathrm{h})$ \\
\hline Hot-Water & & $\mathrm{T}<220^{\circ} \mathrm{C}$ & $\mathrm{h}<943 \mathrm{~kJ} / \mathrm{kg}$ \\
Two-Phase, Liquid-Dominated & Low-Enthalpy & $220^{\circ} \mathrm{C}<\mathrm{T}<250^{\circ} \mathrm{C}$ & $943 \mathrm{~kJ} / \mathrm{kg}<\mathrm{h}<1.100 \mathrm{~kJ} / \mathrm{kg}$ \\
& Medium Enthalphy & $250^{\circ} \mathrm{C}<\mathrm{T}<300^{\circ} \mathrm{C}$ & $1.100 \mathrm{~kJ} / \mathrm{kg}<\mathrm{h}<1.500 \mathrm{~kJ} / \mathrm{kg}$ \\
& High Enthalphy & $250^{\circ} \mathrm{C}<\mathrm{T}<330^{\circ} \mathrm{C}$ & $1.500 \mathrm{~kJ} / \mathrm{kg}<\mathrm{h}<2.600 \mathrm{~kJ} / \mathrm{kg}$ \\
Two-Phase, Vapor-Dominated & & $250^{\circ} \mathrm{C}<\mathrm{T}<330^{\circ} \mathrm{C}$ & $2.600 \mathrm{~kJ} / \mathrm{kg}<\mathrm{h}<2.800 \mathrm{~kJ} / \mathrm{kg}$ \\
\hline
\end{tabular}

Jawa Barat merupakan provinsi yang menghasilkan energi panas bumi terbesar dengan keenam PLTP existing, dimana 1194 MW dari 2130,7 MW atau 56\% dari energi listrik dari PLTP eksisting yang sudah di Indonesia (EBTKE, 2020). Berdasarkan road map panas bumi nasional, tahun 2025 sekitar 39,5\% persen pengembangan nya adalah berada di wilayah Jawa Barat. Jawa Barat memiliki potensi panas bumi yang paling besar di antara 30 provinsi yang ada di Indonesia, dimana total potensi sumber daya yaitu $2159 \mathrm{MW}$ dan total potensi cadangan $3765 \mathrm{MW}$, dan bila di total kedua nya adalah 5924 MW (RUEN, 2017). Bedasarkan data ESDM tentang statistik penjualan tenaga listrik kepada pelanggan rumah tangga dan industri, dimana Jawa Barat menempati urutan pertama konsumsi tenaga listrik pertahun 2019 dengan total konsumsi rumah tangga 18.753,88 GWh dan industri 24.051,64 GWh (ESDM, 2020). Dengan potensi yang besar dan pemanfaatan nya yang masih sekitar $20 \%$ dari potensi yang ada, maka hal ini menjadi tantangan baik bagi pemerintah daerah atau pun pemerintah pusat untuk memaksimalkan potensi geothermal sebagai energi terbarukan untuk memenuhi kebutuhan bauran energi listrik sampai dengan tahun 2025. 


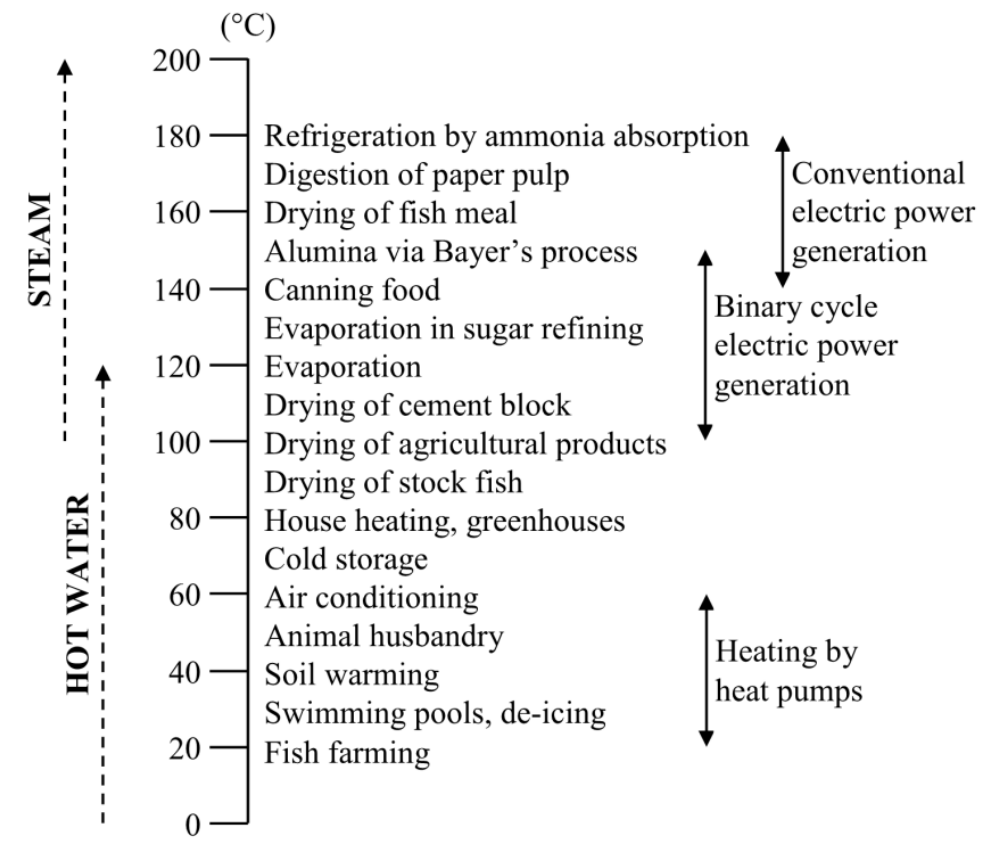

Gambar 1. Lindal Diagram (Ahmadi et al, 2020)

\section{Metodologi}

Metode yang digunakan dalam penelitian ini adalah observasi literatur dari berbagai sumber baik dari Jurnal, data data dari laporan pemerintah pusat, daerah, yang kredibel. Data berisikan data penunjang berupa potensi-potensi sumber energi geotermal. Data sumber energi geotermal diperoleh berdasarkan lokasi sumber di sekitar provinsi Jawa Barat. Data-data literatur yang diperoleh dari berbagai sumber kemudian disusun untuk melakukan review potensi dan pemanfaatannya di daerah Jawa Barat. Sehingga pada penelitian ini bentuk akhir yang akan diperoleh berupa review singkat potensi geotermal di daerah Jawa Barat.

\section{Data Dan Diskusi}

\subsection{Kondisi aktual pengembangan Panas Bumi di Indonesia}

Pada tahun 2014 sampai tahun 2019, ada kenaikan penambahan kapasitas terpasang dari panas bumi dari 1403,3 MW menjadi 2130,7 MW. Peran pemerintah dalam mewujudkan energi ramah lingkungan dengan meningkatkan aksesibilitas masyarakat untuk mendapatkan listrik dapat dilihat pada gambar 2 dengan meningkatnya besaran total nilai kapasitas terpasang pembangkit listrik panas bumi dari tahun 2014 sampai dengan 2019. PLT Panas Bumi memiliki peningkatan dalam hal penyediaan kapasitas terpasang pembangkit EBT sebesar 727 MW sejak tahun 2014. Peningkatan yang signifikan pada sektor panas bumi tidak lepas dari peran penentu arah kebijakan dalam hal mendukung regulasi yang dapat menguntungkan seluruh kalangan terutama dalam hal regulasi dan perizinan. Proses tersebut juga meningkatkan iklim investasi di sektor panas bumi sehingga memungkinkan dapat menarik bertambahnya calon investor baik di dalam maupun luar negeri. Pada tahun 2019, PNBP penerimaan negara bukan pajak, meningkat menjadi Rp. 1,9 trilyun dibandingkan dengan PNPB di tahun 2014 sebesar Rp 756 M dari sektor PLTP. Sedangkan pada Tabel 2 di gambarkan mengenai kapasitas terpasang PLTP yang ada di Jawa Barat, dimana total kapasitas terpasang adalah 1194 MW (ESDM, 2020). 
Dalam perkembangan potensi panas bumi Indonesia adalah 27.483 MW pada tahun 2005, 27.510 MW pada tahun 2006, 27.601 pada tahun 2007 dan 27.670 MW pada November 2008. (Kasbani \& Dahlan, 2008). Pada tahun 2017 potensi panas bumi Indonesia meningkat menjadi 29.544 MW (RUEN, 2017). Jumlah potensi tersebut terdiri dari potensi panas bumi pada kelas sumber daya dan cadangan. Kelas potensi menunjukkan tingkat kelengkapan data yang tersedia. Potensi pada kelas sumber daya didapatkan melalui perhitungan dengan menggunakan metode perbandingan, yaitu dengan membandingkan daya listrik di suatu daerah panas bumi dengan daerah panas bumi lain yang telah berproduksi dan mempunyai kemiripan karakteristik. Adapun untuk potensi pada kelas cadangan didapatkan melalui perhitungan dengan menggunakan metode volumetris dengan menggunakan beberapa asumsi, diantaranya asumsi ketebalan reservoir. Asumsi ketebalan yang digunakan untuk daerah panas bumi di pulau Sumatera dan Jawa adalah $2 \mathrm{~km}$ sedangkan untuk daerah di luar Sumatera dan Jawa adalah 1 km (Kasbani \& Dahlan, 2008).

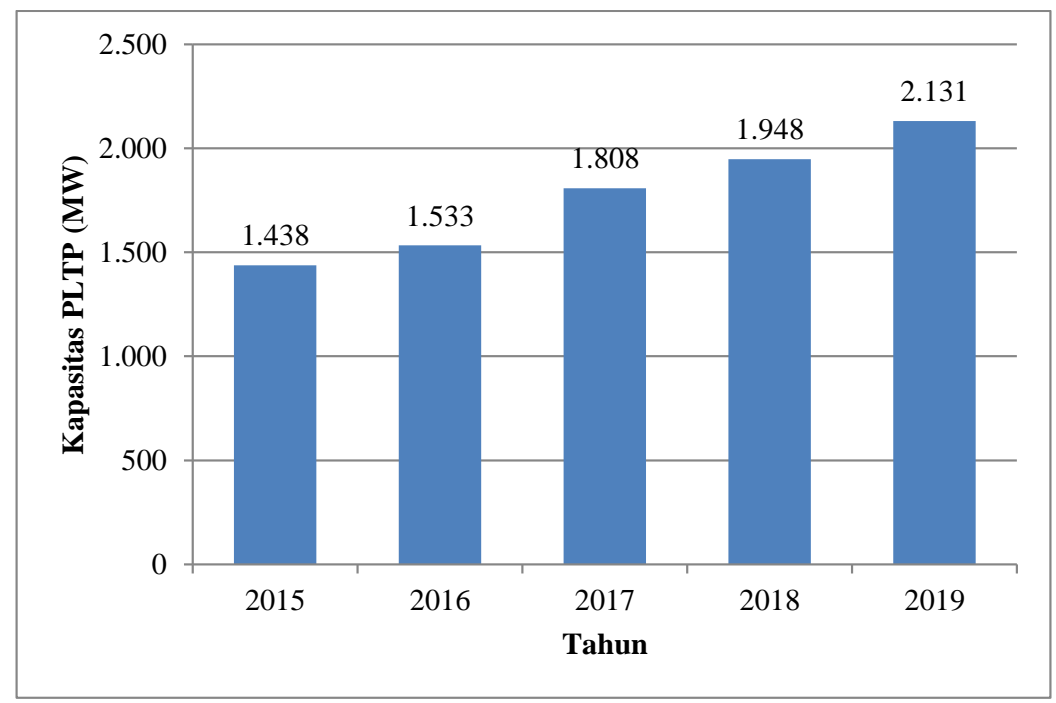

Gambar 2. Kapasitas PLTP Terpasang di Indonesia (ESDM, 2020)

\subsection{Wilayah Kerja Panas Bumi Jawa Barat}

Sesuai dengan program rencana strategis Kementrian ESDM tahun 2020-2024, dimana pemerintah pusat mempunyai target peningkatan bauran energi, pemanfaatan energi baru terbarukan (EBT) menjadi 23\% termasuk peningkatan bauran PLT Panas bumi. Pemerintah menyiapkan 20 Wilayah Kerja Panas bumi (WKP) baru dengan kapasitas total 683 MW. Pemerintah pusat terlebih dahulu melakukan Resource confirmation melalui Survey Geosains - GGG dan Government exploration drilling slim hole di 20 prospek yang merupakan terobosan pertama kali di Indonesia oleh Badan Geologi. Kebutuhan APBN di tahun 2021 sebesar Rp 444 Miliar untuk drilling slim hole di 5 WKP yaitu Cisolok, Jailolo, Nage, Bittuang, Ciremai. Prospek tersebar dari Sumatera sampai Indonesia bagian Tengah dan Timur, Dimana target lelang 20 Wilayah Kerja Panas Bumi pada tahun 2022-2024 sesuai tabel 2 (ESDM, 2020). Pada tabel 3 digambarkan tentang kapasitas terpasang pembangkit listrik panas bumi yang ada di Jawa Barat sampai dengan tahun 2019. 
Tabel 2.

20 WKP Panas Bumi yang akan dilelang 2022 - 2024 (ESDM, 2020)

\begin{tabular}{clccc}
\hline No. & \multicolumn{1}{c}{ Area Prospek } & Status Wilayah & $\begin{array}{c}\text { Sumber } \\
\text { Daya }\end{array}$ & $\begin{array}{c}\text { Rencana } \\
\text { Pengembangan }\end{array}$ \\
\hline 1 & Cisolok, Cisukarame, Jawa Barat & WKP & $45 \mathrm{MW}$ & $20 \mathrm{MW}$ \\
2 & Jailolo, Maluku Utara & WKP & $75 \mathrm{MW}$ & $30 \mathrm{MW}$ \\
3 & Nage, Nusa Tenggara Timur & WKP & $39 \mathrm{MW}$ & $20 \mathrm{MW}$ \\
4 & Bittuang, Sulawesi Selatan & Wilayah Terbuka & $28 \mathrm{MW}$ & $20 \mathrm{MW}$ \\
5 & Ciremai, Jawa Barat & WKP & $60 \mathrm{MW}$ & $55 \mathrm{MW}$ \\
6 & Bora Polu, Sulawesi Tengah & WKP & $123 \mathrm{MW}$ & $40 \mathrm{MW}$ \\
7 & Gunung Endut, Banten & WKP & $180 \mathrm{MW}$ & $40 \mathrm{MW}$ \\
8 & Tampomas, Jawa Barat & WKP & $100 \mathrm{MW}$ & $45 \mathrm{MW}$ \\
9 & Sembalun, Nusa Tenggara Barat & WKP & $100 \mathrm{MW}$ & $20 \mathrm{MW}$ \\
10 & Guci, Jawa Tengah & WKP & $100 \mathrm{MW}$ & $55 \mathrm{MW}$ \\
11 & Sipoholon Ria-Ria, Sumatera Utara & WKP & $60 \mathrm{MW}$ & $20 \mathrm{MW}$ \\
12 & Marana, Sulawesi Tengah & WKP & $70 \mathrm{MW}$ & $20 \mathrm{MW}$ \\
13 & Lokop, Aceh & Wilayah Terbuka & $41 \mathrm{MW}$ & $20 \mathrm{MW}$ \\
14 & Limbong, Sulawesi Selatan & Wilayah Terbuka & $20 \mathrm{MW}$ & $5 \mathrm{MW}$ \\
15 & Maritaing, Nusa Tenggara Timur & Wilayah Terbuka & $190 \mathrm{MW}$ & $30 \mathrm{MW}$ \\
16 & Gunung Batur-Kintamani, Bali & Wilayah Terbuka & $58 \mathrm{MW}$ & $40 \mathrm{MW}$ \\
17 & Gunung Galunggung, Jawa Barat & WKP & $289 \mathrm{MW}$ & $110 \mathrm{MW}$ \\
18 & Papandayan, Jawa Barat & Wilayah Terbuka & $195 \mathrm{MW}$ & $40 \mathrm{MW}$ \\
19 & Banda Baru, Maluku & Wilayah Terbuka & $54 \mathrm{MW}$ & $40 \mathrm{MW}$ \\
20 & Sajau, Kalimantan Utara & Wilayah Terbuka & $17 \mathrm{MW}$ & $13 \mathrm{MW}$ \\
\hline & \multicolumn{1}{c}{ Total } & & $1.844 \mathrm{MW}$ & $683 \mathrm{MW}$ \\
\hline & & &
\end{tabular}

Tabel 3.

Kapasitas Terpasang Pembangkit Panas Bumi di Jawa Barat (ESDM, 2020)

\begin{tabular}{|c|c|c|c|c|c|c|}
\hline No. & Field & & Unit & Total Capacity & Reservoir & Technology \\
\hline \multirow[t]{2}{*}{1} & Salak & Unit-1-3 & $: 3 \times 60 \mathrm{MW}$ & $377 \mathrm{MW}$ & Water Dominated & Single Flash \\
\hline & & Unit 4-6 & $: 3 \times 65,6 \mathrm{MW}$ & & & \\
\hline \multirow[t]{2}{*}{2} & Wayang Windu & Unit-1 & : $110 \mathrm{MW}$ & $227 \mathrm{MW}$ & Water Dominated & Single Flash \\
\hline & & Unit 2 & : $117 \mathrm{MW}$ & & & \\
\hline 3 & Patuha & Unit 1 & : $55 \mathrm{MW}$ & $55 \mathrm{MW}$ & Water Dominated & Single Flash \\
\hline \multirow[t]{4}{*}{4} & Kamojang & Unit-1 & : $30 \mathrm{MW}$ & $235 \mathrm{MW}$ & Vapor Dominated & Dry Steam \\
\hline & & Unit 2-3 & $: 2 \times 55 \mathrm{MW}$ & & & Plant \\
\hline & & Unit 4 & $: 60 \mathrm{MW}$ & & & \\
\hline & & Unit 5 & : $35 \mathrm{MW}$ & & & \\
\hline \multirow[t]{3}{*}{5} & Darajat & Unit-1 & : $55 \mathrm{MW}$ & $270 \mathrm{MW}$ & Vapor Dominated & Dry Steam \\
\hline & & Unit-2 & : $94 \mathrm{MW}$ & & & Plant \\
\hline & & Unit 3 & : $121 \mathrm{MW}$ & & & \\
\hline 6 & Karaha Bodas & Unit-1 & : $30 \mathrm{MW}$ & $30 \mathrm{MW}$ & Water Dominated & Single Flash \\
\hline
\end{tabular}


Berdasarkan Laporan Kementrian ESDM, 2017 mengenai potensi Panas Bumi Indonesia, khusunya di provinsi Jawa Barat adalah sebagai berikut (ESDM, 2017):

1) WKP Cibereum Parabakti

WKP Cibeureum Parabakti, dimana area ini sudah di kelola oleh PT Pertamina Geothermal Energi dan Star Energy Geothermal Salak, kapasitas terpasang 377 MW dalam 6 unit pembangkit, dengan total area luas WKP adalah 102.200 Ha. Sistem panas bumi Awibengkok (Salak) berasosiasi dengan beberapa pusat erufsi volkanik di sekitar gunung Salak. SK WKP 2067 - K/30/MEM/2012. WKP ini berada di dalam hutan konservasi, hutan lindung dan hutan produksi dan sebagian besar di wilayah umum atau lainnya. Sistem panas bumi salak berlokasi di daerah pegunungan dengan kisaran ketinggian antara 950 sampai $1500 \mathrm{~m}$ diatas permukaan laut. Dibagian barat dari geothermal Salak terdapat Cianten Caldera yang merupakan gunung api yang lebih tua.

2) WKP Cibuni

Ijin pengusahaan dipegang oleh PT Kopjasa Keahlian Teknosa. Kawah cibuni ini memiliki cadangan terduga sebesar $140 \mathrm{MW}$, dimana rencana pengembangan adalah $10 \mathrm{MW}$. Total luas WKP adalah 9541 Ha. SK izin pengusahaan 2821K/30/MEM/2015 dimana pemegang ijin adalah PT Kopjasa Keahlian Teknosa.

3) WKP Cisolok Cisukarame

WKP Cisolok Cisukarame, SK WKP 1937/K/30/MEM/2007, saat ini ijin pengusahaan dipegang oleh PT Jabar Rekind Geothermal, dimana diduga memiliki cadangan 45MW dan rencana pengembangan adalah 45 MW. Total luas WKP adalah 15.580 Ha. Sistem panas bumi Cisolok Cisukarame berasosiasi terletak diantara area Cisolok-Cisukarame, area Sangiang (manifestasi airpanas), dan area Gunung Talaga-Halimun dimana didominasi air panas (hot water dominated system) dengan temperature $180-200^{\circ} \mathrm{C}$.

4) WKP Gunung Ciremai

Dimana WKP ini memiliki cadangan terduga sebesar $150 \mathrm{MW}$ dengan rencana pengembangan $110 \mathrm{MW}$. Total luas WKP adalah 38.560 Ha. SK WKP 7633K/30/MEM/2016. WKP gunung ciremai berasosiasi dengan sistem panas bumi yang berasal dari reservoir gunung ciremai, hal ini dicirikan dengan manifest permukaan berupa mata air panas dengan temperature $42^{\circ} \mathrm{C}$ hingga $56,3^{\circ} \mathrm{C}$ yang muncul di daerah Sangkanhurip dan Pejambon. Reservoir Gunung ciremai diperkirakan merupakan reservoir sistem dominasi air panas yang ditunjukan dengan ditemukannya sinter silica di air panas Pejambon.

5) WKP Gunung Galungung

Dimana WKP ini memiliki cadangan terduga sebesar $264 \mathrm{MW}$, dengan rencana pengembangan $110 \mathrm{MW}$. Total luas WKP adalah 57.330 Ha. SK WKP 4284K/30/MEM/2014. Berdasarkan hasil penghitungan geothermometer temperature panas bumi ini adalah $225^{\circ} \mathrm{C}$ dimana sistem panas bumi ini berasosiasi dengan kawah gunung galungung dan perbukitan Sepuluh Ribu.

6) WKP Gunung Gede Pangrango

Dimana WKP ini memiliki cadangan terduga sebesar $85 \mathrm{MW}$ dan rencana pengembangan 55 MW. Total luas WKP adalah 92.790 Ha. SK WKP 2778K/30/MEM/2014 Gunung Gede pangrango memiliki temperature reservoir panas bumi $>225^{\circ} \mathrm{C}$, potensi bahaya geologi 
Gunung Gede merupakan tipe A maka potensi bencana geologi berupa letusan gunung api dapat menjadi kendala.

7) WKP Gunung Tampomas

Dimana WKP ini memiliki cadangan terduga sebesar $50 \mathrm{MW}$ dan rencana pengembangan 45 MW. SK WKP 1790K/33/MEM/2007 dengan total luas WKP adalah 27.010 Ha. Pemegang ijin pengusahaan adalah PT Wijaya Karya Jabar Power. Manifestasi mata air panas yang ditemukan ada di atas gunung Tampomas, dimana berdasarkan perhitungan geothermometer adalah sekitar $187-208^{\circ} \mathrm{C}$.

8) WKP Gunung Tangkuban perahu

Dimana WKP ini memiliki cadangan terduga sebesar $90 \mathrm{MW}$ dan rencana pengembangan 60 MW. SK WKP 2996K/30/MEM/2007 dengan total luas WKP adalah 44.710 MW Ha. Pemegang ijin pengusahaan adalah PT PLN (Persero). Berdasarkan penghitungan geothermometer reservoir panas bumi disekitar WKP Gunung Tangkuban perahu mempunyai temperature $240-320^{\circ} \mathrm{C}$. Luas WKP Tangkuban Perahu secara administratif meliputi Kabupaten Bandung Barat, Kabupaten Subang, dan Kabupaten Purwakarta. Potensi bahaya geologi Tangkuban Perahu meliputi aktivitas gunung api dan longsoran.

9) WKP Kamojang Darajat

Dimana WKP ini pemegang ijin pengusahaan dibawah PT Pertamina Geothermal Energy dan Star Energy Geothermal Darajat. WKP Kamojang Darajat ini memiliki kapasitas terpasang 505 MW. SK WKP 2067K/30/MEM/2012. Dimana luas WKP 45.380 Ha. Berada di wilayah Kabupaten Bandung dan Kabupaten Garut. PT PGE sudah memulai operasional nya dimana unit 1 Kamojang 1 sudah beroperasi di tahun 1983, dengan total 8 unit pembangkit dan unit 8 beroperasi pada tahun 2015 dengan kapasitas 35MW.

10) WKP Karaha Cakrabuana

Dimana WKP ini memiliki cadangan terduga sebesar 190 MW dan kapasitas terpasang 30 MW. Pemegang ijin pengusahaan adalah PT Pertamina Geothermal Energy. SK WKP 2067K/30/MEM/2012 dengan total 64.510 Ha. Area WKP ini berada di Kabupaten Garut. Pada tahap 1 unit 1 PT PGE sudah melakukan commissioning 30 MW di tahun 2018.

11) WKP Pangalengan

Dimana WKP ini dimiliki perusahaan yaitu PT Geodipa (Persero), dan PT Pertamina Geothermal Energy - Star Energy Wayang Windu. Kapasitas terpasang Wayang Windu (1) 110 MW, Wayang Windu (2) 117 MW dan Patuha (1) 55 MW. SK WKP 2067K/30/MEM/2012 dengan luas WKP 152.300 Ha. Star Energy Wayang Windu dan PT PGE membentuk Kontrak Operasi Bersama untuk mengembangkan wilayah ini, dimana Wayang Windu Unit 1 beroperasi di tahun 2000 dan unit 2 beroperasi di tahun 2008. Pada tahun 2014 PT Geodipa Energi (Patuha) mengoperasikan unit 1 Patuha 1 sebesar 55MW.

Ada beberapa potensi di wilayah Jawa Barat yang belum memiliki penetapan WKP oleh pemerintah (ESDM, 2017), antara lain:

1) Potensi Bujal Jasing. Potensi spekulatif adalah sebesar $25 \mathrm{MW}$. Dimana area nya ada disekitar Gunung Endut.

2) Potensi Ciarinem.Potensi spekulatif adalah sebesar $25 \mathrm{MW}$. Areanya berada di sekitar Gunung Papandayan. 
3) Potensi Cibalong. Potensi spekulatif adalah sebesar $25 \mathrm{MW}$. Areanya berada di daerah Cibalong.

4) Potensi Cibingbin. Potensi spekulatif 50 MW. Areanya berada di daerah didekat Gunung Ciremai.

5) Potensi Ciheuras. Potensi spekulatif 25 MW. Areanya berada di daerah CiheurasCipatujah.

6) Potensi Cilayu. Potensi spekulatif 100 MW. Areanya berada di daerah Wayang Windu.

7) Potensi Cipacing. Potensi spekulatif 25 MW. Areanya berada di daerah Gunung Sadakeling dan Gunung Talaga Bodas.

8) Potensi Ciseeng. Potensi Hipotesis 100 MW. Areanya berada di daerah Ciseeng Bogor.

9) Potensi Gunung Cakrabuana. Potensi spekulatif $25 \mathrm{MW}$. Areanya berada di daerah Gunung Cakrabuana.

10) Potensi Gunung kromong. Potensi spekulatif 25 MW. Areanya berada di daerah Gunung Kromong.

11) Potensi Jampang. Potensi spekulatif 225 MW. Areanya berada di daerah Jampang Sukabumi.

12) Potensi Saguling. Potensi spekulatif 25 MW. Areanya berada di daerah Rajamandala.

13) Potensi Subang. Potensi spekulatif $50 \mathrm{MW}$. Areanya berada di daerah Subang.

14) Potensi Tanggeung-Cibungur. Potensi spekulatif 100 MW. Areanya berada di daerah Cianjur.

Dalam laporan lainnya, (Tuti \& Siwage, 2014), ada beberapa faktor yang mempengaruhi dimana perusahaan energi yang ada, dalam hal ini perusahaan pembangkit panas bumi, mengenai ketertarikan nya dalam berinvestasi di Jawa Barat adalah selain karena potensi panas bumi yang besar, hal lainnya adalah karena potensi pasar yang relatif besar, dimana Jawa Barat merupakan provinsi dengan padat penduduk dengan kebutuhan listrik yang terus meningkat, dan di provinsi ini ada berbagai kawasan industri manufaktur yang menjadi penggerak roda perekonomian. Dimana kawasan industri ini memerlukan pasokan energi yang berkesinambungan, dalam hal ini panas bumi merupakan alternatif pembangkit listrik yang menguntungkan. Hal lainnya adalah infrastruktur jaringan ke grid PLN yang sudah relatif maju menjadi salah satu daya tarik kemudahan untuk investor melakukan pengembangan panas bumi di Jawa Barat.

Dalam laporan nya, (Tuti \& Siwage, 2014), menggunakan quantitative strategic planning matrix (QSPM), dimana mengevaluasi strategi alternatif yang berpedoman pada faktor kunci baik eksternal maupun internal yang sudah di identifikasi terlebih dahulu. Dalam penelitian ini dianalisa terhadap PT PGE, PT Indonesia Power, Chevron Geotermal Indonesia (berubah menjadi Star Energy) dan Star Energy. Dari hasil wawancara, perusahaan energi panas bumi memilih di Jawa Barat di bandingkan dengan wilayah lain karena beberapa alasan, karena, pertama potensi yang besar, memiliki lokasi yang dekat dengan pengguna, dan memiliki infrastruktur yang relatif memadai terutama saluran distribusi listrik. 


\subsection{Teknologi Pemanfaatan Pembangkit Listrik Panas Bumi}

Saat ini, ada tiga teknologi pemanfaatan pembangkit listrik panas bumi yaitu dry steam, flash dan binary atau Organic Rankine Cycle (ORC). Dry steam plants dilakukan dengan mengambil uap panas bumi dan langsung digunakan untuk menggerakan turbin untuk memutar generator dan menghasilkan listrik. Teknologi flash steam dilakukan dengan mengambil air panas, biasanya bersuhu lebih dari $200^{\circ} \mathrm{C}$, dan naik ke permukaan kemudian dipisahkan antara air panas dan uap panas, dan uap panas tersebut kemudian dialirkan ke turbin. Sementara binary plant atau ORC, adalah air panas dialirkan ke dalam heat exchanger untuk mendidihkan fluida sekunder dan kemudian memutar turbin (Ronald Dipippo, 2011).

Organic Rankine Cycle sebagai salah satu teknologi dalam pembangkitan listrik yang digunakan dalam pemanfaatan sumber panas bumi dari potensi panas bumi di Indonesia belum di manfaatkan secara maksimal. Pada umumnya beberapa pembangkit yang ada di Indonesia saat ini masih menggunakan sistem single flash steam power plant dan beberapa menggunakan dry steam power plant. Single flash power plant, dimana geofluid yang berasal dari sumur produksi kemudian masuk ke dalam cyclone separator dimana di dalam separator ini dipisahkan antara liquid dan vapor. Kemudian vapor akan masuk ke dalam turbin dan memutar generator untuk menghasilkan listrik. Keluaran dari exhaust turbine dan masuk condenser kemudian didinginkan di dalam cooling tower dan kemudian bergabung dengan liquid yang sudah di pisahkan oleh cyclone separator dan selanjutnya akan dimasukan ke dalam sumur reinjection. Secara sederhana prinsip kerja dari single flash power plant adalah sesuai gambar 3 .

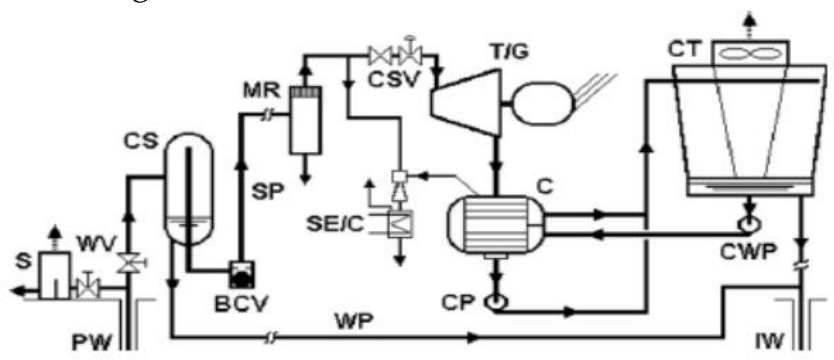

Gambar 3. Single Flash Power Plant (Ronald Dipippo, 2011)

Sedangkan dry steam power plant, dimana dry steam dari sumur produksi kemudian masuk ke dalam particulate removal (pemisah partikel) dan kemudian steam kering masuk kedalam turbin dan memutar generator untuk menghasilkan listrik, selanjutnya dari exhaust turbine masuk ke condenserkemudian masuk ke dalam cooling tower yang selanjutnya didinginkan dan diinjeksikan ke dalam sumur reinjeksi. Gambar 4 adalah skema dari dry steam power plant

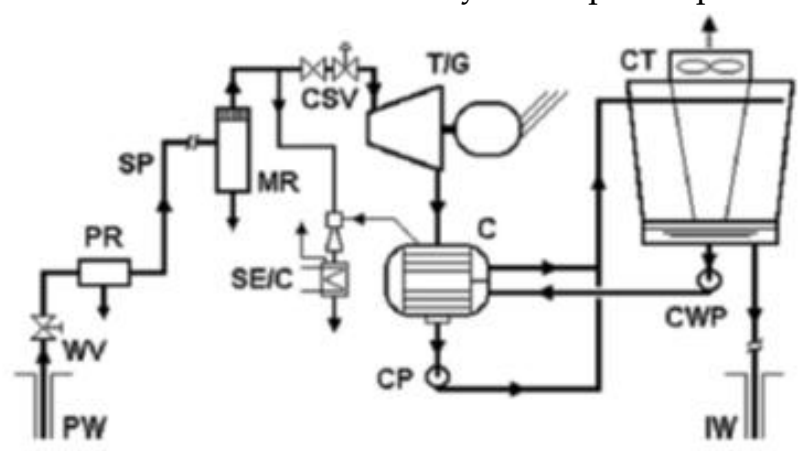

Gambar 4. Dry Steam Power Plant (Ronald Dipippo, 2011) 
Pada sistem ORC sebagai teknologi yang sudah diaplikasikan di beberapa negara, pada sistem ini dimungkinkan untuk memanfaatkan liquid yang dipisahkan dari separator yang dikenal dengan brine dimanfaatkan untuk memanaskan fluida sekunder yang dalam hal ini berasal dari hydrocarbon (HC), hydrofluoroolefins (HFO), dan hydrofluorocarbons (HFC) (Marco Astolfi et all, 2014).

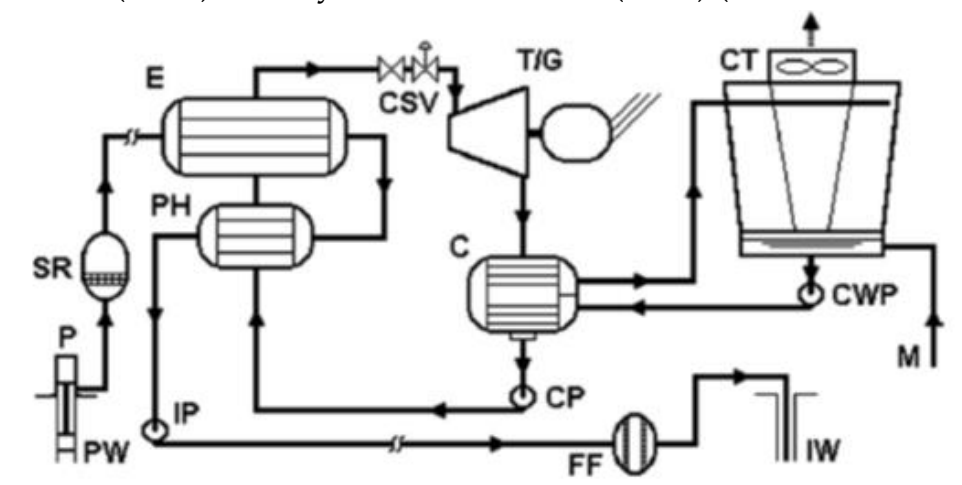

Gambar 5. Skema ORC (Ronald Dipippo, 2011)

\subsection{Gambaran umum \& Tata kelola Panas Bumi di Indonesia \& Jawa Barat}

Dalam hal peraturan perundang undangan Potensi panas bumi untuk konversi tenaga listrik dalam UU Nomor 23 Tahun 2014 pengembangannya sudah menjadi urusan pemerintah pusat, sehingga Pemerintah Proivinsi memiliki kewajiban lainnya yaitu program pembinaan dan pengembangan bidang ketenagalistrikan dan energi. Hal ini sesuai dengan pergub 16 tahun 2016. Sedangkan Pemerintah Kabupaten/Kota hanya dibatasi pada pemanfaatan langsung panas bumi.

Berdasarkan data buku renstra EBTKE 2020-2024, pemerintah melalui EBTKE mempunyai alur untuk menyederhanakan alur proses pengusahaan panas bumi. Hal ini bisa dilihat dari gambar 6 .

Rincian tahapan dalam pengusahaan panas bumi sesuai Undang-Undang Nomor 21 Tahun 2014 Tentang Panas Bumi dan Peraturan Pemerintah Nomor 7 Tahun 2017 tentang Panas Bumi untuk Pemanfaatan Tidak Langsung adalah sebagai berikut:

1) Survei Pendahuluan : kegiatan yang meliputi pengumpulan, analisis, dan penyajian data yang berhubungan dengan informasi kondisi geologi, geofisika, dan geokimia, serta survei landaian suhu apabila diperlukan, untuk memperkirakan letak serta ada atau tidak adanya sumber daya Panas Bumi.

2) Eksplorasi : rangkaian kegiatan yang meliputi penyelidikan geologi, geofisika, geokimia, pengeboran uji, dan pengeboran sumur eksplorasi yang bertujuan untuk memperoleh informasi kondisi geologi bawah permukaan guna menemukan dan mendapatkan perkiraan cadangan Panas Bumi.

3) Studi Kelayakan : kajian untuk memperoleh informasi secara terperinci terhadap seluruh aspek yang berkaitan untuk menentukan kelayakan teknis, ekonomis, dan lingkungan atas suatu rencana usaha dan/atau kegiatan pemanfaatan Panas Bumi yang diusulkan.

4) Eksploitasi : rangkaian kegiatan pada Wilayah Kerja tertentu yang meliputi pengeboran sumur pengembangan dan sumur reinjeksi, pembangunan fasilitas lapangan dan penunjangnya, serta operasi produksi Panas Bumi.

5) Pemanfaatan Tidak Langsung : kegiatan pengusahaan pemanfaatan Panas Bumi dengan melalui proses pengubahan dari energi panas dan/atau fluida menjadi energi listrik. 
Vol. 2, No. 2, pp $60-73$

doi: $10.14710 /$ jebt.2021.11072

Di tahap awal pengembangan, Pemerintah memberi kesempatan kepada lembaga atau institusi penelitian untuk melakukan Penugasan Survei Pendahuluan (PSP) dan badan usaha untuk melakukan Penugasan Survei Pendahuluan dan Eksplorasi (PSPE), sebagaimana tercantum dalam Permen ESDM Nomor 37/2017 tentang Tata Cara PSP dan PSPE Panas Bumi. Pada proses PSPE, badan usaha diberikan kesempatan untuk melakukan proses survei pendahuluan dan eksplorasi selama 3+1+1 tahun dengan menyetorkan dana komitmen eksplorasi sebesar 5\% dari biaya yang ditentukan. Badan usaha untuk PSPE dipilih melalui mekanisme kontes dengan output yang diharapkan berupa hasil survey 3G (Geofisika, Geokimia, Geologi) dan minimal pengeboran 1 sumur eksplorasi.

\begin{tabular}{|c|c|c|c|c|c|c|c|c|c|c|}
\hline Potensil & Potensi & \multicolumn{8}{|c|}{ STADIUM PENGUSAHAAN (S-X) } & \multirow[b]{2}{*}{ Keterangan } \\
\hline Instansi & $\begin{array}{l}\text { Panas } \\
\text { Bumi } \\
\text { (S-0) }\end{array}$ & $\begin{array}{c}\text { Survei } \\
\text { Pendahuluan / SP } \\
\text { (S-1) }\end{array}$ & $\begin{array}{c}\text { Survei Pendahuluan } \\
\text { dan Eksplorasi/ SPE } \\
(\mathrm{S}-2)\end{array}$ & $\begin{array}{l}\text { Penetapan } \\
\text { WKP } \\
(\mathrm{s}-3)\end{array}$ & $\begin{array}{l}\begin{array}{c}\text { Penawaran } \\
\text { WKP }\end{array} \\
\text { (s-4) }\end{array}$ & $\begin{array}{c}\begin{array}{c}\text { Penerbitan } \\
\text { IUP }\end{array} \\
\text { (\$.5) }\end{array}$ & $\begin{array}{c}\text { Eksplorasi- FS } \\
(\mathrm{S}-6)\end{array}$ & $\begin{array}{l}\text { PPA } \\
(s-7)\end{array}$ & $\begin{array}{c}\begin{array}{c}\text { Eksploitasi dan } \\
\text { Pemanfaatan }\end{array} \\
\text { (S-8) }\end{array}$ & \\
\hline $\begin{array}{l}\text { Kementerian } \\
\text { ESDM } \\
\text { (Bageoll } \\
\text { Ditjen EBTKE/ } \\
\text { Ditjen Gatrik) } \\
\end{array}$ & $\begin{array}{c}\text { Peta } \\
\text { Potensi }\end{array}$ & $\begin{array}{l}\text { Biaya } \\
\text { APBN }\end{array}$ & $\begin{array}{l}\text { Biaya } \\
\text { APBN }\end{array}$ & $\begin{array}{c}\text { Evaluasi Laporan } \\
\text { Hasi SP } \\
\text { SPE } \\
\downarrow \\
\text { WKP } \\
\end{array}$ & & & & & & $\begin{array}{l}\text { Penugasan pembelian } \\
\text { dan pengaturan harga } \\
\text { listrik oleh Ditjen Gatrik }\end{array}$ \\
\hline $\begin{array}{l}\text { Pemda Prov./ } \\
\text { Kab./Kota }\end{array}$ & & $\begin{array}{l}\text { Baya } \\
\text { APBD } \\
\end{array}$ & & & & & & & & \\
\hline $\begin{array}{c}\text { Lembagal } \\
\text { Institusi } \\
\text { Penelitian }\end{array}$ & & $\begin{array}{l}\text { Biaya } \\
\text { Pihak } \\
\text { Lain } \\
\end{array}$ & & & & & & & & \\
\hline $\begin{array}{l}\text { Badan } \\
\text { Usaha }\end{array}$ & & & $\begin{array}{l}\text { Biaya } \\
\text { Pihak } \\
\text { Lain } \\
\end{array}$ & & & & & & 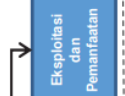 & \\
\hline $\begin{array}{c}\text { PLN } \\
\text { (off taker) }\end{array}$ & & & & & & & & $\begin{array}{l}\downarrow \\
\text { PPA }\end{array}$ & & 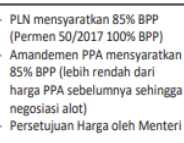 \\
\hline
\end{tabular}

Gambar 6. Alur Pengembangan Panas Bumi

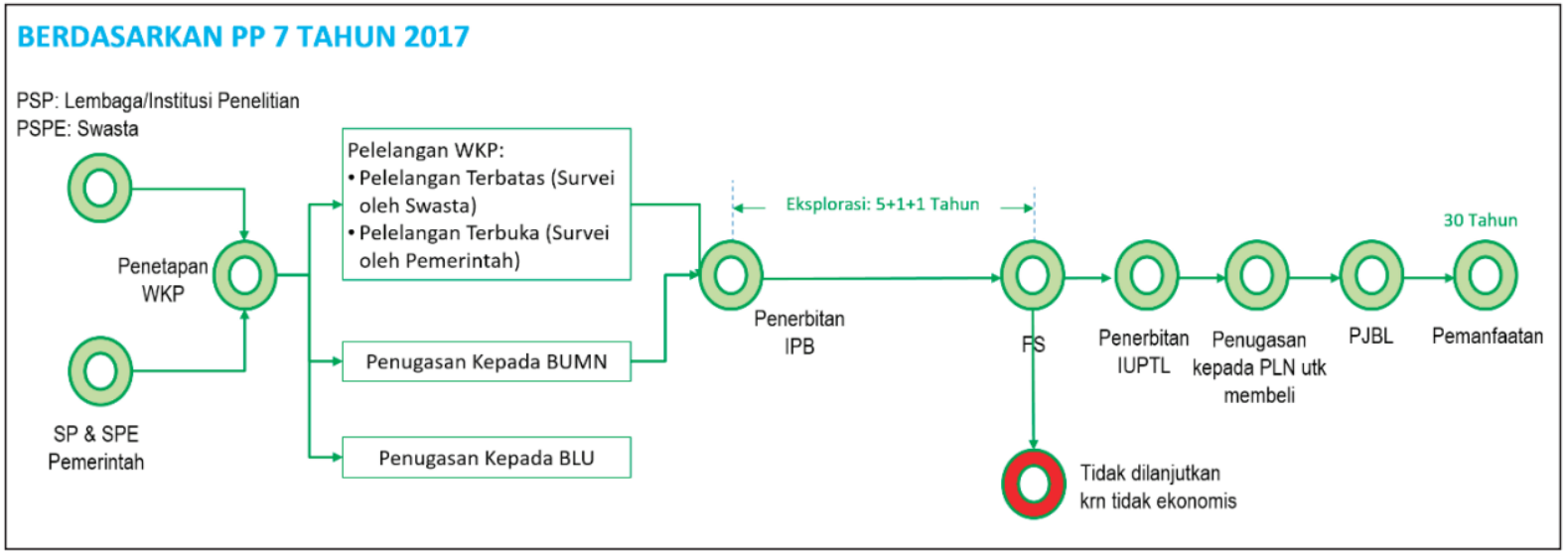

Gambar 7. Pengembangan Panas Bumi 
Sesuai dengan Undang-Undang Nomor 21 Tahun 2014 tentang Panas Bumi yang diturunkan melalui Peraturan Pemerintah Nomor 7 Tahun 2017 tentang Panas Bumi untuk Pemanfaatan Tidak Langsung dijelaskan bahwa proses pengusahaan panas bumi dimulai dari tahapan penyiapan wilayah kerja. Penyiapan wilayah kerja dapat berasal dari skema survei pendahuluan dan eksplorasi yang dilakukan oleh Pemerintah maupun Penugasan Survei Pendahuluan dan Penugasan Survei Pendahuluan dan Eksplorasi yang dilaksanakan oleh Badan Usaha. Tahapan selanjutnya dilakukan kegiatan penawaran wilayah panas bumi kepada Badan Usaha atau dengan memberikan Penugasan pengusahaan panas bumi kepada Badan Usaha Milik Negara. Badan Usaha yang ditetapkan sebagai pemenang lelang maupun yang diberi penugasan oleh Pemerintah akan diberikan Izin Panas Bumi yang ditetapkan oleh Menteri ESDM yang berlaku selama 37 tahun meliputi 5 tahun untuk eksplorasi dengan opsi perpanjangan selama 2 kali masing-masing 1 tahun dan 30 tahun jangka waktu untuk eksploitasi dan pemanfaatan sesuai gambar 7 .

Dalam laporan buku renstra EBTKE 2020-2024, Pemanfaatan dan pengembangan energi panas bumi yang sesuai secara efektif membutuhkan waktu tujuh tahun hingga pembangkit listrik tersebut beroperasi. Akan tetapi, pada realitas di lapangan, proses tersebut memerlukan waktu yang lebih lama yang dikarenakan beberapa tantangan baik dari sisi teknis, ekonomi, lingkungan, dinamika sosial. Ada lima tantangan yang dihadapi dari pihak badan usaha antara lain (ESDM, 2020):

1) Area prospek berada pada kawasan hutan konservasi.

Pemanfaatan panas bumi dapat dilaksanakan pada kawasan konservasi sebagaimana UU Nomor 21 Tahun 2014 tentang Panas Bumi. Akan tetapi, pemanfaatan panas bumi tersebut hanya dapat dilaksanakan pada zona pemanfaatan sebagaimana diatur pada PP Nomor 108 Tahun 2015 tentang Kawasan Pelestarian Alam dan Kawasan Suaka Alam. Saat ini, sebagian area prospek panas bumi teridentifikasi berada pada zona inti yang belum bisa dikembangkan melalui pemanfaatan jasa lingkungan hutan konservasi. Kementerian ESDM dan Kementerian LHK membahas penataan zonasi agar dimungkinkan area prospek panas bumi yang berada pada hutan konservasi dapat dimanfaatkan dengan optimal. Indonesia yang dikenal dengan Tropical Rainforest Heritage of Sumatera (TRHS). Sebagaimana ketentuan dari UNESCO untuk suatu kawasan yang ditetapkan sebagai world heritage tidak dapat dilakukan kegiatan penambangan. Semantara itu, regulasi di Indonesia telah menyatakan bahwa pemanfaatan panas bumi bukan dikategorikan sebagai kegiatan pertambangan. Pemerintah Indonesia telah mempersiapkan position paper untuk mengusulkan pengembangan energi panas bumi pada kawasan TRHS yang tetap dapat dilakukan dengan memperhatikan parameter UNESCO untuk menjaga Outstanding Universal Values (keindahan alam, kelestarian habitat, dan konservasi flora dan fauna) dalam menetapkan suatu kawasan menjadi world heritage. Pengusulan tersebut telah dibahas pada sidang world heritage committee pada Juni 2019. Pemanfaatan energi panas bumi pada zona pemanfaatan di hutan konservasi melalui mekanisme Izin Pemanfaatan Jasa Lingkungan Panas Bumi (IPJLPB) yang saat ini masih disiapkan baik dari tata cara maupun dari kewajiban Badan Usaha untuk mengelola lingkungan. Hal ini sejalan dengan data dari revisi rencana strategis tahun 2013-2018 yang sudah disusun oleh dinas ESDM Jawa Barat, telaahan rencana tata ruang wilayah dimana salah satu faktor penghambat adalah belum optimalnya pemanfaatan potensi sumber daya panas bumi dimana sebagian besar wilayah panas bumi berada di wilayah kehutanan. 
2) Risiko pengembangan Energi Panas Bumi

Pengembangan energi panas bumi mempunyai beberapa risiko yang berbeda-beda di setiap tahapan. Semakin tinggi tahapan pengembangan, risiko akan semakin kecil. Selanjutnya pada tahap Survei Detil, risiko pengembangan akan turun hingga $60 \%$ dan pada tahap pengeboran sumur tingkat risiko pengembangan akan turun menjadi $50 \%$. Pada tahap pengeboran eksplorasi, pengeboran sumur pertama akan menurunkan risiko menjadi $40 \%$ dan pengeboran sumur kedua akan menurunkan risiko menjadi $30 \%$. Selanjutnya pengeboran sumur ketiga hingga kelima akan semakin memperkecil risiko pengembangan menjadi hanya sebesar $20 \%$. Risiko pengembangan pembangkit listrik panas bumi dapat diminimalisir apabila Badan Usaha melakukan pengembangan dengan mengikuti Good Engineering Practices dan evaluasi lapangan secara komprehensif.

3) Efisiensi biaya untuk mencapai keekonomian harga listrik

Besaran risiko pengembangan proyek energi panas bumi dapat mempengaruhi biaya pembangkitan listrik suatu proyek PLTP. Dengan adanya kepastian pendanaan dan juga kepastian pembelian listrik oleh PLN, risiko pengembangan proyek energi panas bumi dapat berkurang sehingga tingkat pengembalian proyek panas bumi (return) masih memenuhi tingkat keekonomian atau kelayakan suatu proyek. Ketersediaan data yang semakin lengkap akan meningkatkan tingkat kepastian cadangan. Pemerintah mendukung keterbukaan data dan informasi energi panas bumi yang telah diperoleh Badan Usaha untuk dilakukan evaluasi bersama dalam rangka mengurangi risiko pengembangan berikutnya. Keekonomian proyek PLTP dapat dicapai bersama-sama dengan melakukan efisiensi pada komponen biaya kapital, seperti efisiensi biaya pengeboran, penerapan teknologi yang tepat, dan pemanfaatan insentif fiskal.

4) Isu sosial

Isu sosial dapat berupa penolakan masyarakat sekitar terhadap pengembangan energi panas bumi. Penolakan masyarakat yang sering terjadi dapat diklasifikasikan menjadi beberapa jenis penolakan, yang pertama penolakan karena isu lingkungan, yaitu masyarakat khawatir dengan adanya proyek panas bumi ketersediaan air akan terganggu dan kekhawatiran kerusakan lingkungan. Penolakan yang kedua sering terjadi karena isu tanah ulayat atau tanah leluhur, yaitu masyarakat menganggap dengan adanya proyek panas bumi akan mengakibatkan hilangnya kesucian lokasi. Bentuk penolakan lain dari masyarakat berkaitan dengan isu adat istiadat daerah sekitar, masyarakat sekitar beranggapan dengan kehadiran proyek panas bumi akan mengganggu budaya dan kebiasaan masyarakat. Proses dinamika penerimaan masyarakat dalam pengembangan energi panas bumi, sejak dalam tahap awal eksplorasi akan berdampak pada kepastian penerbitan izinyang dilakukan oleh Pemerintah Daerah setempat.

5) Pendanaan proyek panas bumi

Permasalahan untuk kegiatan eksplorasi pada umumnya dilakukan dengan menggunakan pembiayaan equity, yang mengakibatkan mayoritas pengembang panas bumi memiliki kemampuan pendanaan yang terbatas untuk dapat membiayai kegiatan eksplorasi khususnya pengeboran yang memerlukan biaya tinggi. Tahapan pengembangan energi panas bumi dibagi dalam tiga tahap utama, yaitu tahap eksplorasi, eksploitasi dan operasi. Risiko pengembangan energi panas bumi pada tahap eksplorasi masih sangat tinggi 
sehingga terbatasnya lembaga keuangan, baik lokal dan internasional, yang mau memberikan pinjaman modal. Pengembang energi panas bumi harus menggunakan modal sendiri (equity) untuk melakukan kegiatan eksplorasi. Oleh karena itu, badan usaha yang dapat melaksanakan proyek panas bumi sesuai dengan tata waktu pengembangan yang ideal membutuhkan kekuatan finansial yang sehat.

\section{Kesimpulan}

Jawa Barat merupakan provinsi yang menghasilkan energi panas bumi terbesar dengan keenam PLTP existing, dimana 1194 MW dari 2130,7 MW atau 56\% dari energi listrik dari PLTP eksisting yang sudah berproduksi. Berdasarkan road map panas bumi nasional, tahun 2025 sekitar 39,5\% pengembangannya berada di wilayah Jawa Barat. Hal ini menjadi keuntungan karena di dukung oleh Pemerintah pusat dalam hal ini melalui Survey Geosains - GGG dan Government exploration drilling slim hole. Jawa Barat memiliki potensi 11 wilayah yang sudah memiliki SK WKP dan 14 wilayah yang belum memiliki ijin WKP dan atau ijin pengusahaan. Dalam pengembangan PLT Panas Bumi ini ada beberapa teknologi yang bisa di aplikasikan diantaranya single flash steam plant, dry steam plant dan binary (ORC) plant. Teknologi tersebut bisa diaplikasikan secara individual atau gabungan di sesuaikan dengan kondisi aktual dilapangan. Dalam konteks pengelolaan pengembangan PLT Panas Bumi ada banyak tantangan yang harus di hadapi oleh pengembang panas bumi baik dari ijin pengelolaan wilayah WKP yang berada di wilayah Hutan Konservasi, Hutan Lindung dan lainnya, masalah pembiayaan, dan resiko pengembangan PLT panas bumi perlu menjadi perhatian utama selain isu sosial, masalah pembiayaan dan tarif PLT Panas Bumi itu sendiri.

\section{Daftar Pustaka}

A. Ahmadi, M. El haj. Assad, D.H.Jamali, R.Kumar, Z.X.Li, T. Salameh, M. Al-Shabi, M.A. Ehyaei, 2020. "Application of Geothermal Organic Rankine Cycle for Electricity Production".

Alison Holm DJ, Blodgett Leslie. 2012, "Geothermal energy and greenhouse gas emissions geothermal energy association".

Dirjen Energi Baru Terbarukan dan Konversi Energi, 2020, "Buku Rencana strategis 2020-2024"

ESDM 2017, "Potensi Panas Bumi Indonesia, Jilid 1"

ESDM, 2020, “Ringkasan Rencana Strategis 2020 - 2024"

Eylem Kaya. SJZ, O'Sullivan Michael. J, 2011, "Reinjection in geothermal fields: a review of worldwide experience", Renew Sustain Energy Rev.

Kasbani, Dahlan, "Potensi dan Wilayah Kerja Panas Bumi Tahun 2008"

Marco Astolfi, Matteo C. Romano, Paola Bombarda, Ennio Macchi, 2014. “Binary ORC (Organic Rankine Cycles) power plants for the exploitation of mediumelow temperature geothermal sources e Part B": Techno-economic optimization

Nasruddin, M. Idrus Alhamid, Yunus Daud, Arief Surachman, Agus Sugiyono, H.B. Aditya, T.M.I. Mahlia, 2016, "Potential of geothermal energy for electricity generation in Indonesia: A review"

Peraturan Presiden RI, “Rencana Umum Energi Nasional (RUEN)”, No. 22 Tahun 2017

Ronald Dipippo, Phd, Geothermal Power Plants: principle, application, case studies, anenvironment impact, Thrid Edition, 2011

Tuti. Ermawati, Siwage. D. Negara, 2014, “Pengembangan Industri Energi Alternatif : studi kasus Energi Panas Bumi Indonesia" 